\title{
Socialization to gender roles and marriage among Egyptian adolescents
}

\author{
Barbara Mensch \\ Population Council \\ Barbara L. Ibrahim \\ Population Council \\ Susan M. Lee \\ Omaima El-Gibaly
}

Follow this and additional works at: https://knowledgecommons.popcouncil.org/departments_sbsr-pgy

Part of the Demography, Population, and Ecology Commons, Family, Life Course, and Society

Commons, Gender and Sexuality Commons, and the International Public Health Commons

How does access to this work benefit you? Let us know!

\section{Recommended Citation}

Mensch, Barbara, Barbara L. Ibrahim, Susan M. Lee, and Omaima El-Gibaly. 2000. "Socialization to gender roles and marriage among Egyptian adolescents," Policy Research Division Working Paper no. 140. New York: Population Council. 


\section{Socialization to Gender Roles and M arriage Among Egyptian Adolescents}

Barbara S. Mensch

Barbara L. I brahim

Susan M. Lee

O maima EI-Gibaly 


\title{
Socialization to Gender Roles and Marriage Among Egyptian Adolescents
}

\author{
Barbara S. Mensch \\ Barbara L. Ibrahim \\ Susan M. Lee \\ Omaima El-Gibaly
}

Barbara S. Mensch is Senior Associate, Policy Research Division, Population Council, New York. Barbara L. Ibrahim is Senior Associate and Regional Director for West Asia and North Africa, Population Council, Cairo. Susan M. Lee was a fellow at the Population Council, Cairo when this paper was begun and is now a consultant to the Population Council. Omaima El-Gibaly is Lecturer, Department of Public Health and Community Medicine, Assiut University.

This paper was prepared for presentation at the Annual Meeting of the Population Association of America, Los Angeles, March 2000. An earlier version, focusing on boys and titled "Transitions to manhood: Socialization to gender roles and marriage among Egyptian adolescent boys," was presented to the seminar on Men, Family Formation, and Reproduction, hosted by the International Union for the Scientific Study of Population and Centro de Estudios de Población, Buenos Aires, Argentina, 13-15 May 1998. 


\begin{abstract}
Using nationally representative survey data, this paper explores gender role socialization and attitudes toward marriage among unmarried Egyptian adolescents aged 16-19 years. We examine the daily activities of adolescent boys and girls, views about age at marriage and desirable qualities in a spouse, and various indicators of gender role attitudes including opinions about whether wives should defer to husbands, about sharing household decisionmaking, and about responsibility for domestic tasks. Our findings reflect strong gender differentiation: girls have much less free time than boys, are much less mobile, are much less likely to participate in paid work, and have heavier domestic responsibilities regardless of whether or not they are in school. Girls favor a later age at marriage for both sexes, but particularly for boys. Boys are significantly more likely than girls to favor educational inequality between spouses. While neither boys nor girls have particularly progressive gender role attitudes, girls are significantly more likely to express less traditional attitudes. Multivariate analyses indicate that girls' and boys' attitudes do not vary consistently and significantly by socioeconomic background; in particular, increased schooling does not always promote egalitarian attitudes. The implications of these findings for policies and programs are discussed.
\end{abstract}

This material may not be reproduced without written permission from the authors. 
Given the growing interest in gender and adolescents within the development field, it is surprising how little attention has been paid to the process of gender role acquisition among young people. Few large-scale data-collection efforts in developing countries have focused on adolescents at all, and those that have tend to be interested in so-called risky behaviors such as drug-taking or unprotected sex rather than in developmental processes (e.g., Raymundo, Xenos, and Domingo 1999; Morris 1994). While there is a growing literature on women's empowerment (e.g., Balk 1997 and Kishor 1995) and its impact on demographic outcomes (e.g., Kishor 2000; Durrant and Sathar 2000) there is little research, outside small-scale psychological studies, on how or when adult gender roles are produced.

This paper helps to close this research gap through the analysis of survey data on adolescents in contemporary Egypt. To our knowledge, it is the first systematic effort to explore issues of gender role socialization in Egypt or, for that matter, anywhere in the developing world using a national data set. ${ }^{1}$ We are particularly interested in the differences in gender role socialization for girls and boys, in a society characterized by distinct and often segregated roles for men and women (Sayed and El-Zanaty 1993; Kandiyoti 1994). Not only does our data set provide measures of gender role attitudes at a formative stage of the life cycle, it also includes these for boys as well as girls, unlike surveys limited to older populations.

Understanding gender role acquisition is important for many reasons, especially for what it may foretell about later behavior, including reproductive behavior; access to and control over resources, especially as related to investments in children; physical mobility and labor force participation of women; and the family relationships these boys and girls will eventually form. Moreover, if attitudes differ between the sexes, this may presage conflicts at a later stage of life. For example, are boys' attitudes about appropriate roles for women keeping pace with the trends for greater female education and employment (El-Zanaty et al. 1996), now firmly established in Egypt?

\section{PREVIOUS RESEARCH}

\section{Gender role socialization}

In response to concern about the consequences of premarital childbearing and rising rates of $\mathrm{HIV}$ infection, much of the existing research on adolescence in the developing world focuses on sexual activity and contraceptive use among the unmarried (e.g., 
Alan Guttmacher Institute 1998; McCauley and Salter 1995; Singh et al. 2000). These issues are not as salient in Egypt and other developing countries in the Middle East and South Asia as they are elsewhere; moreover, limiting analysis to risk-taking behaviors ignores many of the significant "tasks" of adolescence, such as obtaining work skills and preparing for adult reproductive and family roles. Studies that isolate deviant behavior fail to examine the fuller social context in which young people grow to adulthood.

To the extent that data exist on adolescent socialization in the developing world, it is qualitative and has come primarily from two comparative ethnographic projects. One, known as the Harvard Adolescence Project, involved field work in seven sites, although only two of the studies from developing countries—one on Morocco, discussed below, and another on Nigeria — have been published (Davis and Davis 1989). The other project drew on 186 small-scale studies to investigate how societies "locate" the adolescent life stage in their social arrangements (Schlegel and Barry 1991); while this comparative study examines gender roles, the focus is on discovering patterns across societies rather than on undertaking detailed analysis of gender role socialization in any one place as we do here, for Egypt.

The Harvard project pays more explicit attention to gender role acquisition during adolescence and includes a rich study of growing into adulthood in a Moroccan town (Davis and Davis 1989). Moroccan adolescents were described as experiencing increasing differential role socialization, or gender intensification, during this age period. Parents were deeply involved in conveying gender norms through shared participation in domestic tasks and monitoring of their children's mobility. Girls' activities outside the home were increasingly monitored and restricted as they reached adolescence, much more than those of their adolescent male siblings. Further, adolescent girls were expected to assume greater responsibilities in the household while their male counterparts were able to escape much of this responsibility. Ethnographic work in Egypt suggests similar patterns (Hoodfar 1997). ${ }^{2}$

The scant literature on adolescent socialization focuses mainly on the roles of family, peers, and the media. Systematic research is lacking on the ways in which the process and content of formal schooling affect the maturation of girls and boys (Lloyd and Mensch 1999). Indeed, the specific mechanisms through which education exerts its influences on young people are not fully understood. Formal schooling is a channel 
through which young people are inculcated with norms and values and exposed to new ideas. The curriculum and textbook content, interpersonal interactions within and outside the classroom (including teacher-student and student-student interactions), extracurricular activities, and formal administrative rules and regulations are obvious vehicles through which messages regarding gender and other social norms are transmitted. Formal schooling may also impart a set of skills related to personal efficacy, problemsolving, and social negotiation (Wassef 1996; Furnham and Stacey 1991).

Scholars disagree on whether the schooling experience in developing countries has a modernizing effect on gender role attitudes. Many researchers, noting the remarkably consistent associations found between women's years of formal schooling and delayed age at marriage and reduced fertility, attribute the effect to the increased autonomy that girls acquire through schooling (Jejeebhoy 1995). Others have challenged the notion that schooling enhances the autonomy of girls, noting the traditional gender role messages conveyed by teachers and textbooks and the fundamentally conservative nature of schooling (Jeffery and Basu 1996). Egyptian school texts contain clear messages about the appropriate roles for women and men in society. Despite recent revisions to textbooks to enhance the image of women, the gender content of the curriculum maintains fairly traditional gender roles (Wassef 1996). Ibrahim and Wassef (2000) note that while the curriculum plays lip service to principles of equality between the sexes, the underlying discourse asserts these equal rights in different domains: women contribute to society as wives and mothers while men have control of the public domain. A review of history and civics textbooks revealed that "[w]ith few exceptions, women....are depicted in supporting roles rather than independent or leadership positions" (Ibrahim and Wassef 2000:6). The authors refer to a quotation from the religion text used in the third year of secondary school: "The upright community is founded upon the collaboration of men and women in the family, and the collaboration of men and men in society."

In addition to exposing adolescents to new ideas, school can potentially shift the orientation of a young person from adults to peers. Schooling places adolescents in a peer context for most of the day, reducing the amount of time they spend with adults and increasing "the salience of their involvement with age-mates" (Schlegel 1995b:29). However, it is unclear what role peers play in the socialization of developing-world adolescents. In the West, peer involvement is linked with tendencies toward delinquency, 
especially among boys in some social settings (Schlegel 1995a). On the other hand, some researchers have found that peer associations among developing-country youth are more likely to be experienced as "extensions of parental relationships rather than as counter forces that introduce youth to anti-cultural values" (Youniss 1989:387).

\section{Female autonomy}

Social scientists are interested in gender role socialization because it can shed light on the question of how adult autonomy is produced. Recent years have witnessed an increasing interest in women's autonomy in particular, because of its potential association with reproductive behavior and child outcomes. (See Federici, Mason, and Sogner 1993 for a discussion of how demographers became interested in this issue; and Mason 1987, 1993 for a discussion of the theoretical linkages between women's status and demographic change.)

Since the early 1980s when Dyson and Moore (1983) noted an association between women's autonomy and demographic behavior at the state level in India, the empirical literature on this subject has grown. Although definitions of autonomy vary, researchers have demonstrated with survey data that the social position of women, as measured by such indicators as physical mobility, decisionmaking autonomy, and access to resources, is significantly associated with contraceptive use, fertility, child mortality, and investments in children's schooling (for recent studies see Kishor 2000; Durrant and Sathar 2000; Hossain et al. 2000). When they are available, direct measures have been used to measure women's empowerment; where such measures are absent, proxies such as the educational level and employment status of women, and the age and educational differences between spouses have also been employed (see Uchudi 2000), although there is not always a strong or significant association between the proxies and the more direct measures (Kishor 1999; Balk 1997). And, since it has been established that the status of women can be an important factor in demographic change, there is also interest in exploring the social determinants of women's autonomy (e.g., Balk 1997).

\section{The Middle Eastern ConteXt}

Perhaps because of the established links between women's status and demographic outcomes, an implicit assumption is made that the goal of adulthood everywhere is greater 
autonomy. When researchers apply a concept such as autonomy to Middle Eastern societies, however, the underlying factor they may be identifying is an ability to effectively mobilize or influence one's social relationships rather than an ability to act independently per se - the more conventional definition of autonomy (see Nawar, Lloyd, and Ibrahim 1995).

Many observers have pointed to the collective nature of social life in Arab societies and to the central role played by family members in shaping the values and selfconceptions of individuals (Joseph 1994; Rugh 1999). Young people typically live at home until marriage and remain dependent on elder family members for financial and emotional support as young adults. One implication of this is that adolescent experience in Egypt is less likely to be characterized by rebellion or social distancing from parents than is the case in Western societies (Davis and Davis 1989).

Young people may experience adolescence more as a time of refining interpersonal skills than one of achieving autonomy. Joseph (1993) also develops the idea of "connectivity" to describe the intertwined nature of self and significant others in a young person's emerging sense of identity and agency. This is a central construct for both men and women in Middle Eastern societies, though each experiences it differently. It implies that, in Egypt, the important task of adolescent socialization is learning how to mobilize social networks rather than becoming autonomous as a means of achieving personal goals.

In investigating gender role socialization in Egypt, one confronts gender stereotypes that are embedded in broader stereotypes about Middle Eastern society (Said 1978). Some of these stereotypes about men and women prevail both inside and outside the region, suggesting their roots in socially accepted conceptions of gender identity. Males are presumed to be authoritarian in their relations with women, to uphold the segregation of gender roles, to take control of fertility decisions, and to maintain emotional distance from wives and children (Davis and Davis 1989; Kandiyoti 1994). Women are expected to be generally submissive to men and confined by social norms to roles within the family. Compared to men, they are believed to display more warmth and emotionality (Rugh 1999). Although we do not discuss how these characterizations emerged and are sustained, we are able to assess how well some of these constructs reflect the reported attitudes and behaviors of contemporary Egyptian adolescents. In particular, we 
are interested in detecting signs of movement away from expected gender role patterns among subgroups of boys or girls.

Because some of the qualities of female adult role identity described above are also traits associated with children, girls' socialization is likely to follow quite a different path from that of boys. Boys must negotiate a period in adolescence in which they are still subordinate because of their young age, while beginning to take on the privileges of manhood. This may create some internal conflicts, but generally implies a continuous increase in autonomy and mobility (Davis and Davis 1989; Kandiyoti 1994). On the other hand, Egyptian girls in adolescence have traditionally experienced an abrupt end to the relative freedom and mobility they enjoyed in childhood (Ibrahim and Wassef 2000). Around the time of puberty, girls are expected to display increasing modesty and to withdraw from some public spaces to which they had access as children. As Egypt experiences rapid social change, the question for researchers is whether changes are also emerging in socialization patterns, and which social groups display greatest movement away from expected gender role socialization.

\section{DATA}

In 1997, a nationally representative sample survey, known as Adolescence and Social Change in Egypt (ASCE), was conducted in Egypt among 9,128 adolescent girls and boys ages 10 to 19 and a sample of their parents (El-Tawila et al. 1999). ${ }^{3}$ The main survey collected information on education, work roles, and daily activities. In addition, one-quarter of randomly selected adolescents were systematically subsampled for a health module. The 2,323 adolescents in the subsample were given laboratory tests on urine, stool, and blood and were asked questions on health practices, dietary habits, and attitudes toward reproductive health and gender roles, such as maturational changes and desirable age at marriage. For those 16 and older, questions were asked on reproductive health knowledge, gender roles within marriage, and desirable qualities in a spouse. The analysis in this paper is restricted to the 660 (weighted $n=674$ ) unmarried adolescents in the health subsample aged 16 to 19 and their parents (or other responsible adults). ${ }^{4}$ All results presented below have been weighted according to standard procedures. 


\section{Plan OF ANALYSis}

In what follows we seek to understand emerging gender role attitudes and experiences among a nationally representative sample of unmarried Egyptian girls and boys aged 16-19. We examine several topics relevant to gender role acquisition in Egypt: school access and continuation among adolescents, how parents view education for boys and girls, time use among adolescents, adolescent attitudes toward the timing of marriage and spouse selection, whether adolescents think wives should be deferential to their husbands, how they believe important decisions should be made between married couples, and what they expect with regard to roles and responsibilities in their adult lives.

In societies such as Egypt, where social norms for appropriate gender role behavior are strongly sanctioned, girls and boys will be expected to display their femininity or masculinity by producing the expected, normative answers to questions about their views and expectations (Tessler et al. 1987). However, to the extent that significant patterns emerge from the survey data, we may be able to isolate some of the factors behind nontraditional responses, pointing the way to openings for programmatic or policy action.

Many of the analyses conducted for this paper are descriptive; the primary goal is to assess differences between boys' and girls' socialization. A secondary objective is to clarify the significance of education in influencing the socialization of Egyptian young people. Thus, for dependent variables measuring attitudes toward age at marriage and age differences between spouses as well as gender role attitudes, multivariate models are also presented to estimate the relative weight of background factors in explaining variability among groups of boys and girls. Included in these models, in addition to education of the adolescent, are socioeconomic variables that can be considered exogenous: education of the mother and the father, region of residence, and socioeconomic status as measured with a household consumption index. To minimize the risk of reverse causality - that is, the possibility that gender role attitudes of adolescents affect their educational attainment—we made the highest adolescent education category "above preparatory" rather than "completed secondary" because not all 16-19-year-olds would have had a chance to complete secondary school. On the other hand, all of our 16-19year-olds have had the chance to be in the "above preparatory" category since prepara- 
tory school typically is completed by age 14 . In other words, the decision to attend school beyond the preparatory level should have been made prior to the survey for all respondents, assuming no one is more than two years behind grade for their age. Indeed, everyone in the sample aged 16-19 who is currently in school has completed preparatory school.

The parental education variables include different categories than the adolescent education variable-reflecting the fact that older Egyptians are less likely to have gone to school and the fact that they have completed their schooling; thus "no schooling" is the reference category and "secondary and above" is the highest category. "Missing" categories are included because information on educational attainment was not always available for both parents, and we did not want to eliminate cases with missing information given the small sample size. The residence variable is divided into the standard regional categories for Egypt: Lower Egypt is the Nile Delta while Upper Egypt is the Nile Valley south of Cairo. The four urban governorates are Cairo, Alexandria, Port Said, and Suez. Socioeconomic status is measured by a household consumption index; a missing category is again included because of a desire not to lose cases when information is not available. ${ }^{5}$

\section{Education: A Potential Agent of Socialization}

As noted previously, education is believed to be a central component of socialization in contemporary societies. Certainly the child who is deprived of schooling will have limited opportunities and experiences compared to those who went to school, and will not be exposed to one of the key channels through which socialization occurs. Access to education and the amount of schooling completed are powerful predictors of many subsequent behaviors and attitudes. Moreover, differential access to education is an important indicator of gender inequality in a society. Since the decision to enroll a child in school is generally made by parents, and their perceptions about schooling may color children's experience, parental attitudes are also explored here as an element of socialization.

The Egyptian educational system consists of five years of primary, three years of intermediate (preparatory), and three of secondary school. The first eight years, known 
as basic education, should be free and compulsory, but many factors restrict access of some children and prevent others from completing all eight years. The adolescent girls in our sample entered primary school between 1984 and 1987. They were disadvantaged in those years relative to boys in their likelihood of entering school. Of the boys aged 16-19, approximately 3 percent have never been to school, compared to about 14 percent of girls, a substantial and significant difference $(\mathrm{p}<.001)$.

On the other hand, if a girl was initially enrolled, the probability that she remained in school is almost equal to that of a boy. Table 1 indicates that educational attainment among adolescents who have attended school is virtually the same for boys and girls. Indeed, the differences between boys and girls are not significant. To the extent then that there is a gender gap in educational attainment among young people in Egypt today, the difference is entirely attributable to girls' not entering school at the same rate as boys. It is not a consequence of a gender difference in the propensity to drop out. ${ }^{6}$

We would expect this recent progress in Egyptian education to be reflected in a "generation gap." In fact, the pattern of educational attainment experienced by this generation of adolescents differs considerably from that of their parents. The gender gap in initial enrollment was much wider among the older generations, represented in the sample of responsible adults. Moreover, once a girl in the parents' generation entered school, she was much more likely to drop out than a boy (data not shown).

To some extent, traditional values about education still hold sway among parents. It is not that adults generally believe boys should go to school and girls should not-

Table 1 Educational attainment of unmarried adolescents who ever attended school: Percent of boys and girls aged 16-19

\begin{tabular}{lcc}
\hline & $\begin{array}{c}\text { Boys } \\
(\mathbf{N = 3 6 7 )}\end{array}$ & $\begin{array}{c}\text { Girls } \\
(\mathbf{N}=\mathbf{3 0 0})\end{array}$ \\
\hline Some primary & 10.4 & 9.7 \\
Completed primary & 13.4 & 13.0 \\
Completed preparatory & 4.9 & 7.7 \\
Above preparatory & 71.4 & 69.7 \\
\hline
\end{tabular}

Note: Differences between boys and girls are not statistically significant. 
indeed, when asked separately about how long boys and girls should continue in school, about three-quarters of adults gave the same response for both, with only 11 percent favoring boys and 6 percent favoring girls. ${ }^{7}$ Rather, parents give different reasons why their sons and daughters should attend. While about half believe that education benefits girls by providing better and more-lucrative job opportunities, more than 70 percent believe schooling conveys this advantage for boys. Moreover, while 47 percent of adults respond that education makes a boy a better parent and helps him deal better with life, more than two-thirds of adults indicate that education provides these benefits for a girl. Finally, for a substantial fraction of adults—about 20 percent-education is thought to improve girls' chances of finding a suitable husband, whereas only about 5 percent say that schooling facilitates the process of finding a suitable wife. ${ }^{8}$

While we expect that adolescents' experiences and perceptions have been influenced by the recent expansion in education, we also hypothesize that these parental attitudes, coupled with the fact, noted earlier, that official textbooks in Egypt convey traditional gender roles, will color the way school is experienced by boys and girls, and may be a factor in the observed consequences of education discussed below.

\section{DAILY ACTIVITY AND LEISURE}

Education is a dominant activity in the daily schedule of adolescents who are still in school. Knowing the time-use patterns of those who are out of school and the ways that school is integrated with other activities for students will reveal a great deal about socializing environments for young people. The lack of comprehensive data on adolescents in the developing world has left us with little understanding of how they spend their time. Traditionally in Egypt, as noted above, puberty leads to a greater restriction on girls' mobility outside the home in order to ensure chastity and preserve family honor. Boys, on the other hand, are permitted greater mobility and are expected to increase the amount of time devoted to work outside the home and community involvement. Schooling has had a major impact on those patterns, extending the ages when girls are able to be out in public, increasing contact between boys and girls, and delaying the onset of work. In Egypt, however, where the school year is much shorter than in most other countries and where double-shift schools are common, even those adolescents who attend school may have much unscheduled time available to them. 
The ASCE survey included a set of questions asking adolescents to recall specific activities they engaged in the day before the interview. ${ }^{9}$ These data provide us with a sense of which activities are most prominent in young people's lives and how those activities differ between boys and girls. This can give us insight into the extent of early role segregation and the potential difference in socialization that occurs during a formative life stage. Adolescents' patterns of time use might also reveal avenues for outreach in future intervention programs targeted to adolescents.

Table 2 identifies broad categories of time use and gives the percentage of girls and boys who reported participating in various activities on the day before the interview separately by whether or not the adolescent was currently attending school. While boys and girls 16 to 19 were about equally likely to watch television or listen to the radio, boys were much more apt to engage in activities outside the home. A significantly greater percentage of boys went out with friends, worked, and participated in sports. This pattern holds true regardless of current school attendance. Moreover, higher socioeconomic status, at least as broadly measured by educational attainment and the consumption in-

Table 2 Gender differences in activities reported for previous day among unmarried boys and girls aged 16-19

\begin{tabular}{|c|c|c|c|c|}
\hline & \multicolumn{2}{|c|}{ In school } & \multicolumn{2}{|c|}{ Out of school } \\
\hline & $\begin{array}{c}\text { Boys } \\
\left(\begin{array}{c}\mathrm{N}=192) \\
\%\end{array}\right.\end{array}$ & $\begin{array}{c}\text { Girls } \\
\left(\begin{array}{c}\mathrm{N}=165) \\
\%\end{array}\right.\end{array}$ & $\begin{array}{c}\text { Boys } \\
(\mathbf{N}=\mathbf{1 8 8}) \\
\%\end{array}$ & $\begin{array}{c}\text { Girls } \\
(\mathbf{N}=129) \\
\%\end{array}$ \\
\hline Domestic work $* * *$ & 26 & 68 & 17 & 92 \\
\hline Paid work $* * *$ & 9 & $<1$ & 42 & 7 \\
\hline $\begin{array}{l}\text { Media activities } \\
\text { (television and radio) }\end{array}$ & 88 & 87 & 80 & 85 \\
\hline Activity with friend $* * *$ & 56 & 12 & 51 & 11 \\
\hline Visited friends' homes*** & 40 & 15 & 41 & 18 \\
\hline Visited relatives' homes $* *$ & 26 & 15 & 34 & 24 \\
\hline Prayed at home $* * *$ & 33 & 53 & 23 & 46 \\
\hline Visited mosque ${ }^{* * *}$ & 39 & 4 & 45 & 1 \\
\hline Sports or exercise $* * *$ & 17 & 0 & 12 & 0 \\
\hline
\end{tabular}

Note: Differences between boys and girls significant at $* * * p<.001 ; * * \mathrm{p}<.01$. With the exception of "visited relatives' homes," wherever in-school differences are significant, so are out-of-school differences. 
dex, does not result in greater participation in activities outside the home for girls (data not shown).

Domestic work. One stereotype of Egyptian men suggests that they do not participate in domestic chores. Thus, the levels of reported domestic work by boys in this survey are noteworthy. Especially at younger ages, boys report a significant level of participation, about 50 percent for those ages 10-12, declining to about 20 percent among 16-19-year-olds (data not shown).

Predictably, girls' participation in domestic work is high and, in contrast to boys', does not vary by age: 76 percent of girls 10-12 and 79 percent of those 16-19 were engaged in domestic activity on the day before the interview. Moreover, girls' participation in domestic work is consistently higher than boys' even when accounting for school enrollment. Among the adolescents 16-19 who are currently attending school, 26 percent of boys and 68 percent of girls reported doing domestic work the previous day. ${ }^{10}$

Helping at home appears to be expected of both boys and girls during childhood and early adolescence, though clearly higher expectations are placed on girls. As they age, boys gradually withdraw from this responsibility, widening the gender role division by the late teens. The activity profile that emerges by late adolescence reflects the expected patterns for Middle Eastern societies: boys have considerably more free time than girls, and they tend to spend that time outside the home, with friends, engaged in sports, or visiting friends' homes. Work roles become gradually segregated, with boys more likely to participate in paid labor while girls participate in domestic work within the household.

Mobility and peer relations. As noted above, girls in Egypt have traditionally been restricted in their mobility outside the home as they begin to mature physically, while boys gain increasing freedom with age. While many aspects of Egyptian life are changing rapidly, the ASCE data suggest that these norms remain for most Egyptian adolescents. In particular, boys have significantly more contact with peers than girls do. For example, 55 percent of boys aged 10-12 reported socializing with a friend the previous day, compared to 30 percent of girls. While among boys virtually the same percentage of 16-19-year-olds as 10-12-year-olds reported spending time with friends (54 percent for 16-19-year-olds), only 12 percent of the older girls reported spending time with friends, a substantial decline with age. Boys retain the freedom to associate with 
their peers as they mature, while girls' peer-related activities decrease. In short, girls, throughout adolescence, spend much of their nonschool time confined to activities within the home. This allocation of time can be seen as preparation for the segregated domestic and public roles that adult women and men are expected to perform.

\section{AtTitudes Toward Marriage Age}

Marriage is a fundamental social institution in Egypt and a nearly universal experience. More than 98 percent of men by age 40 and of women by age 35 have been married at least once (Sayed et al. 1992). Age at marriage, however, varies greatly between men and women. Teenage marriage for girls has been of concern for a number of reasons, including increased risk of poor pregnancy outcomes for those who bear children at very young ages (El-Tawila et al. 1999; El-Zanaty et al. 1996). Furthermore, while it is difficult to separate cause from effect, early marriage is associated with limited education and work experience (Singh and Samara 1996). In addition, young brides in Egypt are more likely to marry men considerably older than themselves, thereby increasing both the likelihood of substantial power differentials within marriage and the probability of earlier widowhood (El-Zanaty et al. 1996). For these reasons, delaying age at marriage is key to improving women's status (Mensch et al. 1998).

In fact, age at marriage is rising among women in Egypt. The percentage of women married by age 20 decreased from 65 percent of those aged 45-49 to 41 percent of those aged 20-24 (El-Zanaty et al. 1996). Among adolescent girls in the ASCE survey, 12 percent reported that they were currently or had been married. This figure ranges from around 5 percent in the urban governorates to 20 percent in rural Upper Egypt. Nevertheless, Egypt still has one of the lowest mean ages at marriage for women in the Arab world (Singh and Samara 1996).

We expect that young people's attitudes toward marriage age will be a sensitive indicator of movement away from the more traditional aspirations prevalent in earlier generations. The ASCE survey asked respondents at what age it is suitable for a man to marry, and at what age it is suitable for a woman. Boys' and girls' average responses are not far from the national norms: boys believe that women should marry at age 20.2, while girls think women should marry at age 20.6 ( $p<.05)$. However, the gender gap is much wider where ideal ages for men are concerned. Girls indicate that men should 
marry at a later age than boys themselves say they should, nearly two years older. Whereas the response given by girls for desirable age at marriage for men is 25.9, the boys' response is 24.1 ( $\mathrm{p}<.001)$. For the most part, this gender gap remains within educational and regional groups. ${ }^{11}$

That adolescent boys in Egypt are more inclined to favor early marriage than are girls may be related to the financial requirements of marriage; these have become so great for young men that few have hopes of marrying as early as they wish. This is both a burden and a frustration for boys, who have limited opportunities to interact with girls before marriage and limited venues for sexual activity outside of marriage. Boys' preference for a younger age for girls to marry probably reflects conventional attitudes that younger brides are more innocent and malleable. Girls, on the other hand, may want more opportunities for their own education and employment before marrying, or fear that their families might pressure them to marry someone not of their choosing. Delaying the event may be a way of increasing girls' leverage in the decisionmaking process (Nawar et al. 1995). Girls probably prefer a later age for boys to marry on the assumption that this will increase their future husband's financial resources and maturity.

Multivariate models of "suitable" marriage age provide some support for these hypotheses. Table 3 presents results from OLS regression models with selected background variables. For boys, controlling for education as well as other characteristics, higher family socioeconomic status is associated with favoring a lower marriage age for women and men, although only significantly for men. That is, boys from wealthier homes think a young age at marriage for boys is suitable, probably because they can afford to get married earlier. For girls, higher family socioeconomic status is associated with supporting a higher marriage age for women and men, although only significantly for women. ${ }^{12}$ This is consistent with a view that girls from more affluent homes see advantages in delaying marriage.

\section{SELECTING A SPOUSE}

The appropriate selection of a spouse is considered critically important in Egypt for consolidating the family's social status and for ensuring future compatibility of the couple. Thus, the process usually involves parents, older siblings, and other relatives, in 
Table 3 OLS regression models of characteristics associated with suitable marriage age, unmarried boys and girls aged 16-19

\begin{tabular}{|c|c|c|c|c|}
\hline & \multicolumn{2}{|c|}{ Boys } & \multicolumn{2}{|c|}{ Girls } \\
\hline & $\begin{array}{l}\text { Suitable age } \\
\text { for men }\end{array}$ & $\begin{array}{c}\text { Suitable age } \\
\text { for women }\end{array}$ & $\begin{array}{c}\text { Suitable age } \\
\text { for men }\end{array}$ & $\begin{array}{c}\text { Suitable age } \\
\text { for women }\end{array}$ \\
\hline $\mathbf{N}$ & 356 & 356 & 274 & 274 \\
\hline Adjusted R ${ }^{2}$ & .17 & .20 & .06 & .22 \\
\hline \multirow[t]{2}{*}{$\mathbf{F}$} & $4.56 * * *$ & $5.52 * * *$ & $1.88 *$ & $4.76 * * *$ \\
\hline & Coefficients & Coefficients & Coefficients & Coefficients \\
\hline \multicolumn{5}{|l|}{$\begin{array}{l}\text { Adolescent's education } \\
\text { (omitted=did not } \\
\text { complete primary) }\end{array}$} \\
\hline Completed primary & $2.16^{* *}$ & .89 & -1.23 & .06 \\
\hline Completed preparatory & $2.77 * * *$ & $1.01 *$ & .60 & $1.47 * *$ \\
\hline Above preparatory & $3.39 * * *$ & $1.25 * *$ & .19 & $1.45 * * *$ \\
\hline \multicolumn{5}{|l|}{$\begin{array}{l}\text { Mother's education } \\
\text { (omitted=no schooling) }\end{array}$} \\
\hline Did not complete primary & .96 & .52 & -.30 & -.37 \\
\hline Completed primary/any preparatory & ry .64 & -.28 & .00 & -.58 \\
\hline Vocational, above intermediate & $2.69 * *$ & $1.40 *$ & .02 & 1.02 \\
\hline Secondary and above & 1.10 & -.14 & .49 & $1.46^{*}$ \\
\hline Missing & .51 & -.59 & .72 & .89 \\
\hline \multicolumn{5}{|l|}{$\begin{array}{l}\text { Father's education } \\
\text { (omitted=no schooling) }\end{array}$} \\
\hline Did not complete primary & 1.02 & .48 & $-2.57 * * *$ & -.11 \\
\hline Completed primary/any preparatory & ry -.28 & $1.12 * *$ & -.51 & -.05 \\
\hline Vocational, above intermediate & .44 & -.45 & -.36 & .08 \\
\hline Secondary and above & .70 & .55 & .20 & -.77 \\
\hline Missing & -.29 & .31 & -.25 & -.20 \\
\hline \multicolumn{5}{|l|}{$\begin{array}{l}\text { Residence } \\
\text { (omitted=Upper Egypt, rural) }\end{array}$} \\
\hline Upper Egypt, urban & 1.24 & $2.20 * * *$ & .02 & .10 \\
\hline Lower Egypt, rural & .60 & $1.07 * *$ & -.18 & .15 \\
\hline Lower Egypt, urban & 1.13 & $2.79 * * *$ & 1.01 & -.03 \\
\hline Urban governorates & .99 & $2.34 * * *$ & -.09 & $1.27 * *$ \\
\hline \multicolumn{5}{|l|}{$\begin{array}{l}\text { Socioeconomic status } \\
\text { (omitted=low) }\end{array}$} \\
\hline Medium & -.77 & -.01 & .14 & -.28 \\
\hline High & $-1.26^{*}$ & -.12 & $1.29 *$ & .37 \\
\hline Missing & $-2.25 * * *$ & -.58 & 1.17 & -.71 \\
\hline Constant & 21.08 & 17.49 & 25.72 & 19.39 \\
\hline
\end{tabular}

Note: Differences between boys and girls significant at $* \mathrm{p}<.05 ; * * \mathrm{p}<.01 ; * * * \mathrm{p}<.001$. 
addition to the couple themselves. Family discussions often focus on the characteristics of a potential suitor or the general qualities one should look for in a suitable marriage partner. Thus, adolescents grow up in an environment in which they become familiar with prevailing norms concerning the qualities of a "good" husband or wife well before reaching an age at which this is an active concern in their own lives. (Such an environment may predispose them, however, to answer a survey question on this topic in terms of family or community expectations.)

Other research in Arab countries has found a clear disjunction between the romantic courtship ideals of adolescent boys and the expectations for choosing a partner as expressed by elders. Elsewhere it has been noted that boys' interest in finding a girl who could "love and understand" them was at sharp odds with the patriarchal gender attitudes they expressed in terms of their envisioned marital roles (Davis and Davis 1989). Where gender differences in ideal spousal characteristics are great, these may presage difficulties in finding a suitable partner and could lead to future areas of conflict within marriage.

The ASCE survey asked boys and girls aged 16 and older to name the most important qualities they would seek in a wife (for boys) or husband (for girls). Multiple responses were encouraged. The analysis that follows looks at gender differences in responses (see Table 4). Responses are not displayed by schooling level of the adolescent because, for the most part, the qualities sought in a spouse do not vary systematically by education. Since other gender role attitudes are more sensitive to education level, this finding may reflect the strength of prevailing norms about the nature of marriage and ideal spouses throughout Egyptian society. ${ }^{13}$

There is fairly close agreement among boys and girls concerning aspects of "ascribed" status: a small percentage wants a spouse who is related to them, and owning land is rarely mentioned. Most significant gender differences are related to "achieved" characteristics. Girls prefer a husband who has a strong character, who is good natured, will treat them well, and who has wealth or a good job. Boys, in contrast, are more likely to seek a wife who is "virtuous," religious, well mannered, and comes from a good family. These differences are paralleled by the very different expectations adolescents express regarding decisionmaking roles and responsibilities in marriage: men are pro- 
Table 4 Qualities sought in a future spouse: Percent of unmarried boys and girls aged 16-19 mentioning each attribute

\begin{tabular}{lcc}
\hline & Boys $(\mathbf{N}=351-352)$ & Girls (N=279-280) \\
\hline Love & 22.2 & 25.4 \\
Strong character*** & 5.4 & 28.9 \\
Virtuous* & 14.8 & 8.2 \\
Sensible & 10.5 & 9.6 \\
Good nature*** & 17.0 & 33.2 \\
Treats well*** & 9.7 & 18.9 \\
Wealth*** & 2.0 & 15.7 \\
Land & 0.3 & 1.1 \\
Educated & 35.2 & 32.6 \\
Related & 2.3 & 0.7 \\
Religious* & 43.5 & 35.5 \\
Polite, well brought-up*** & 79.8 & 64.5 \\
Good job*** & 2.8 & 18.6 \\
Good family*** & 38.5 & 19.6 \\
\hline
\end{tabular}

Note: Differences between boys and girls significant at *p<.05; ***p<.001.

viders; women are nurturers (see below). They are also consistent with the religious and legal obligations of Muslim husbands and wives (Naguib and Lloyd 1994).

Given these divergent profiles of an ideal spouse, it is noteworthy that an equal proportion—about one-quarter-of girls and boys would seek a spouse who loves and understands them, an attribute associated more closely with romantic courtships and a companionate style of marriage. The majority of boys and girls appear to adhere to the traditional view that love should follow and not precede marriage. The most frequently mentioned characteristic by far, for boys and girls, is "polite, well brought-up." The term in Arabic, mu adab, encapsulates a range of attributes relating to norms of proper social interaction in the family and community. That adolescents mention this attribute so frequently suggests the degree to which they have internalized the notion that successful adulthood is achieved by knowing and practicing "polite" social skills.

Interestingly, there is also not a significant difference in the percentage of boys and girls wanting an educated spouse. However, gender differences emerge regarding 
whether spouses should have similar education (data not shown). When asked whether it is desirable for a husband and wife to have equal amounts of schooling, boys are more inclined to say no: 45 percent of boys compared to 28 percent of girls think that a husband should have more education than his wife, a large and significant difference that persists within levels of schooling, although it is not systematically or significantly related to the level of schooling attained. ${ }^{14}$

If girls' attitudes toward education are predictive of future behavior, specifically their inclination to send their own daughters to school, it would appear that the educational gap between men and women in Egypt is likely to be reduced further (El-Kholy 1997). On the other hand, boys' greater resistance to equitable levels of schooling is a potential source of conflict in families. As higher proportions of girls continue to reach advanced educational levels, these male attitudes could also affect women's marriage prospects.

Adolescents were also asked what the best age difference should be between a husband and wife, or whether they should be the same age. This question was thought to be important because a large age difference, particularly when marriage takes place during a girl's adolescence, may result in a power disparity and the wife's having limited ability to negotiate with her spouse about domestic matters. In Egypt, age differences between spouses are typically sizable. Analysis of DHS data reveals that nearly two-thirds of teenage brides marry men more than five years older and nearly one-quarter marry men ten or more years older; by contrast, among women who marry in their 20s, the comparable figures are 43 percent and 12 percent (Mensch, Bruce, and Greene 1998: 66).

Table 5 indicates that boys are more inclined to favor a smaller age difference between spouses than are girls. Indeed, approximately 16 percent of girls favor a difference greater than five years, compared to 5 percent of boys. This finding is not consistent with an expectation that boys would favor a larger gap in order to exert greater power or control. For girls, education is the only variable that appears to contribute to differences in their attitudes. When desired age difference reported by adolescents is examined separately by educational level, there is a significant and positive association among girls but not among boys (see Table 6). For example, over one-fifth of girls who have gone beyond preparatory school favor an age difference of more than five years, 
Table 5 Attitude toward desirable age difference between spouses: Percent of unmarried boys and girls aged $16-19$

\begin{tabular}{lcc}
\hline & $\begin{array}{c}\text { Boys } \\
(\mathbf{N}=\mathbf{3 6 0}) \\
\mathbf{\%}\end{array}$ & $\begin{array}{c}\text { Girls } \\
(\mathbf{N = 2 8 8}) \\
\mathbf{\%}\end{array}$ \\
\hline Same age or not important & 20.8 & 20.8 \\
Husband 1-3 years older & 46.4 & 21.5 \\
Husband 4-5 years older & 27.8 & 42.0 \\
Husband 6-10 years older & 5.0 & 15.6 \\
Mean age difference & 2.8 years & 3.8 years \\
\hline
\end{tabular}

Note: Differences between boys and girls significant at $\mathrm{p}<.001$.

compared to 7 percent of those who completed primary. Moreover, although diminished, this association with educational level among girls remains when other factors are controlled in a multivariate model (see Table 7).$^{15}$ Perhaps the reasoning behind this attitude is financial: among better-educated girls, the older the husband, the more likely he is to have established himself and be economically secure. However, girls need only wait until they reach social and physical maturity, which occurs at an earlier age. Thus better-educated girls may see an economic rationale for a large gap whereas those who are not educated, and whose prospects for advancement are thus limited, do not.

Table 6 Percent of unmarried boys and girls aged 16-19 who believe that a husband should be more than five years older than his wife, by level of education

\begin{tabular}{lcc}
\hline & $\begin{array}{c}\text { Boys } \\
(\mathbf{N}=\mathbf{3 5 8})\end{array}$ & $\begin{array}{c}\text { Girls } \\
\mathbf{( N = 2 8 7 )} \\
\text { \% }\end{array}$ \\
\hline Did not complete primary & 0.0 & $\mathbf{\%}$ \\
Completed primary & 2.4 & 0.0 \\
Completed preparatory & 8.5 & 6.9 \\
Above preparatory & 5.3 & 18.0 \\
\hline
\end{tabular}


Table 7 OLS regression models of desirable age difference between spouses, unmarried boys and girls aged $16-19$

\begin{tabular}{lcc}
\hline & Boys & Girls \\
\hline $\mathbf{N}$ & 358 & 287 \\
Adjusted $\mathbf{R}^{2}$ & .10 & .11 \\
$\mathbf{F}$ & $3.01^{* * *}$ & $2.83^{* *}$ \\
\hline & Coefficients & Coefficients
\end{tabular}

Adolescent's education

(omitted=did not complete primary)

Completed primary

$.06--.04$

Completed preparatory

.74

.27

Above preparatory

$.68^{*}$

$1.00^{*}$

Mother's education (omitted=no schooling)

Did not complete primary

$1.70 * * *$

.27

Completed primary/any preparatory

.24

.84

Vocational, above intermediate

.43

.53

Secondary and above

$-.34$

.62

Missing

Father's education $($ omitted=no schooling)

Did not complete primary

$-.71$

.11

Completed primary/any preparatory

$-.48$

$1.24 *$

Vocational, above intermediate

Secondary and above

Missing

$-.82 *$

Residence (omitted=Upper Egypt, rural)

Upper Egypt, urban

Lower Egypt, rural

$-.07$

Lower Egypt, urban

$-.18$

Urban governorates

$-.16$

Socioeconomic status (omitted=low)

Medium

High

Missing

Constant

Note: Differences between boys and girls significant at $* \mathrm{p}<.05 ; * * \mathrm{p}<.01 ; * * * \mathrm{p}<.001$. 


\section{Gender Role AtTitudes}

Ideas about what constitutes appropriate gender role behavior are being publicly debated in Egypt as elsewhere. We posit that boys and girls who have more-egalitarian attitudes toward gender roles will be better prepared as they enter adulthood to adapt to contemporary demands on families - for dual incomes, for flexible child-care arrangements, and for taking advantage of greater gender equality in access to education and training. Respondents aged 16-19 in the ASCE health sample were asked a series of questions regarding whether the wife should defer to a husband's wishes and about sharing household decisions and household tasks.

Table 8 shows the percentage of girls and boys who agree with various statements regarding whether wives should defer to husbands. A fairly patriarchal view of gender relations between husband and wife emerges. The vast majority of both male and female respondents agree that the wife "needs her husband's permission for everything." A smaller, though still substantial percentage believe that a wife must accept a husband's opinion if she differs with him, that a wife must defer to the husband when it comes to spending "money left over after a household's needs are met," and that a wife must comply with the husband's views about childbearing. Moreover, in contrast to the first statement, for which there is nearly universal support from both sexes and thus no gender difference, girls are significantly less likely to support the other three statements than are boys.

Table 8 Adolescent attitudes regarding whether wife should defer to husband: Percent of unmarried boys and girls aged 16-19 agreeing

\begin{tabular}{lccc}
\hline & $\begin{array}{c}\text { Boys } \\
(\mathbf{N = 3 5 6 - 3 6 8 )} \\
\mathbf{\%}\end{array}$ & $\begin{array}{c}\text { Girls } \\
(\mathbf{N = 2 7 4 - 2 8 8})\end{array}$ & \\
Agree that & 91.8 & 87.5 & Significance \\
\hline $\begin{array}{l}\text { Wife needs husband's permission } \\
\text { for everything }\end{array}$ & 74.5 & 56.4 & $\mathrm{p}<.001$ \\
$\begin{array}{l}\text { If a woman differs with her husband, } \\
\text { she must accept his opinion }\end{array}$ & 76.8 & 48.2 & $\mathrm{p}<.001$ \\
$\begin{array}{l}\text { Husband should decide how to spend } \\
\text { surplus income }\end{array}$ & 50.3 & 42.3 & $\mathrm{p}<.05$ \\
\hline \begin{tabular}{l} 
If husband wants children, wife must comply \\
\hline
\end{tabular}
\end{tabular}


Table 9 shows the percentage of girls and boys who expressed the view that various aspects of decisionmaking should be a) confined to the husband or wife alone or b) shared between husband and wife. Girls are uniformly more likely to prefer sharing; gender differences are significant for all seven topics. The relative unwillingness of boys to share decisions about whether a wife should work outside the home warrants further investigation. This could reflect an unrealistic hope among boys that they will have wives who stay home to care for them, since an increasing number of couples, especially in urban areas, require dual incomes to meet financial needs (El-Zanaty et al. 1996). It is also possible that this subject has been a source of conflict within their current household, and by keeping the sole right to decide, boys believe these conflicts could be avoided.

In addition to sharing household decisions, we assessed the degree to which adolescents consider it desirable for husbands and wives to share in particular household and childrearing tasks-for example, breadwinner, housekeeping, caring for children (see Table 10). Interestingly, both boys and girls are more willing to accept sharing of family decisions between husband and wife than sharing of tasks and roles. One expla-

Table 9 Adolescent attitudes regarding who should be responsible for decisionmaking: Percent of unmarried boys and girls aged 16-19 (Boys N=362-369; Girls N=282-289)

Note: Differences between boys and girls significant at $* \mathrm{p}<.05 ; * * \mathrm{p}<01 ; * * * \mathrm{p}<.001$. 
nation could be that it is more acceptable to share some aspects of authority within marriage than to actually have males perform tasks that are traditionally defined as feminine (or vice versa). Alternatively, adolescence may be a developmental period in which "intensification" of gender roles leads to an exaggerated preference for role segregation. Adult realities may mute these responses in the future.

To better understand what accounts for differences among boys and girls regarding gender role identity, we created three additive indexes from the various components displayed in Tables 8-10. A high score for each index indicates that these activities and decisions should be shared and that the wife does not need to seek the husband's permission nor must always defer to his opinion. Table 11 provides the possible ranges in each index and the mean scores. For all three indexes, girls have significantly more progressive attitudes than boys, even for the two indexes for which both sexes have low scores.

Table 12 indicates how these scores vary by level of adolescent schooling. While the differences are significant for the deferential score and the decisionmaking score for

Table 10 Adolescent attitudes regarding who should be responsible for household tasks: Percent of unmarried boys and girls aged 16-19 (Boys N=220-365; Girls N=235-289)

\begin{tabular}{|c|c|c|c|c|c|c|}
\hline & \multicolumn{2}{|c|}{ Husband alone } & \multicolumn{2}{|c|}{ Wife alone } & \multicolumn{2}{|c|}{$\begin{array}{c}\text { Both husband } \\
\text { and wife }\end{array}$} \\
\hline & $\begin{array}{c}\text { Boys } \\
\%\end{array}$ & $\begin{array}{c}\text { Girls } \\
\%\end{array}$ & $\begin{array}{c}\text { Boys } \\
\%\end{array}$ & $\begin{array}{c}\text { Girls } \\
\%\end{array}$ & $\begin{array}{c}\text { Boys } \\
\%\end{array}$ & $\begin{array}{c}\text { Girls } \\
\%\end{array}$ \\
\hline Be the breadwinner & 86.9 & 83.7 & 0.3 & 1.7 & 12.8 & 14.5 \\
\hline Buy provisions & 23.3 & 22.3 & 70.7 & 66.6 & 6.0 & 11.1 \\
\hline Wash clothes $* * *$ & 1.1 & 0.7 & 98.6 & 95.5 & 0.3 & 3.8 \\
\hline Cook* & 1.4 & 0.7 & 97.2 & 94.8 & 1.4 & 4.5 \\
\hline Feed children $* *$ & 4.0 & 0.7 & 88.8 & 95.2 & 7.2 & 4.1 \\
\hline Bathe children* & 0.0 & 0.7 & 97.9 & 94.1 & 2.1 & 5.2 \\
\hline Play with and supervise children** & 7.3 & 1.5 & 55.2 & 63.3 & 37.5 & 35.2 \\
\hline Take children to school* & 53.6 & 41.3 & 21.4 & 31.5 & 25.0 & 27.2 \\
\hline Help children with homework*** & 32.9 & 16.4 & 23.1 & 31.6 & 43.9 & 52.0 \\
\hline Take children to doctor $* * *$ & 59.2 & 31.0 & 14.0 & 17.8 & 26.8 & 51.2 \\
\hline
\end{tabular}

Note: Differences between boys and girls significant at $* \mathrm{p}<.05 ; * * \mathrm{p}<.01 ; * * * \mathrm{p}<.001$. 
Table 11 Mean gender role attitude scores ${ }^{\mathrm{a}}$ of unmarried boys and girls aged 16-19

\begin{tabular}{lcc}
\hline & $\begin{array}{c}\text { Boys } \\
(\mathbf{N = 3 8 0})\end{array}$ & $\begin{array}{c}\text { Girls } \\
(\mathbf{N = 2 9 4})\end{array}$ \\
\hline Wife not deferential to husband $(0-4)^{* * * *}$ & 1.0 & 1.6 \\
Spouses share decisionmaking $(0-7)^{* * * *}$ & 4.5 & 5.7 \\
Spouses share tasks $(0-10)^{* * *}$ & 1.2 & 1.9 \\
\hline
\end{tabular}

Note: Differences between boys and girls significant at $* * * p<.001$.

aPossible range of attitude score for each opinion is shown in parentheses.

both sexes, only the deferential score shows a systematic association with education. As seen in Table 13, the positive association of education with this gender attitude score remains significant in a multivariate model. ${ }^{16}$ Note that the percentage of variation explained is higher for the girls' model than for the boys' model. That is, girls' attitudes are influenced by exposure to schooling and urban residence more so than are boys'; for example, the coefficients for the adolescent education variable are larger and more highly significant for girls, suggesting that boys' attitudes are more deeply entrenched. For girls, more so than for boys, some aspect of the schooling experience encourages them to challenge normative ideas about gender-segregated roles. In addition, among girls,

Table 12 Gender role attitude scores of unmarried boys and girls aged 16-19 by level of education (Boys N=380; Girls N=294)

\begin{tabular}{|c|c|c|c|c|c|c|}
\hline & \multicolumn{2}{|c|}{$\begin{array}{l}\text { Wife not } \\
\text { deferential } \\
\text { to husband }\end{array}$} & \multicolumn{2}{|c|}{$\begin{array}{c}\text { Spouses share } \\
\text { decisionmaking }\end{array}$} & \multicolumn{2}{|c|}{$\begin{array}{c}\text { Spouses } \\
\text { share tasks }\end{array}$} \\
\hline & $\begin{array}{c}\text { Boys } \\
\%\end{array}$ & $\begin{array}{c}\text { Girls } \\
\%\end{array}$ & $\begin{array}{c}\text { Boys } \\
\%\end{array}$ & $\begin{array}{c}\text { Girls } \\
\%\end{array}$ & $\begin{array}{c}\text { Boys } \\
\%\end{array}$ & $\begin{array}{c}\text { Girls } \\
\%\end{array}$ \\
\hline Did not complete primary & .6 & .7 & 4.3 & 5.2 & 1.4 & 1.7 \\
\hline Completed primary & .7 & 1.0 & 3.9 & 5.5 & 1.2 & 1.8 \\
\hline Completed preparatory & 1.0 & 1.6 & 4.1 & 5.4 & 1.1 & 1.7 \\
\hline Above preparatory & 1.2 & 2.0 & 4.9 & 6.0 & 1.2 & 2.1 \\
\hline Significance & \multicolumn{2}{|c|}{$\mathrm{p}<.001 \mathrm{p}<.001$} & \multicolumn{2}{|c|}{$\mathrm{p}<.001 \mathrm{p}<.01$} & N.S. & N.S. \\
\hline
\end{tabular}

Note: See Table 11 for possible range of attitude score for each of the three opinions. 
Table 13 OLS regression models of deferential attitude score, unmarried boys and girls aged $16-19$

\begin{tabular}{lcc}
\hline & Boys & Girls \\
\hline $\mathbf{N}$ & 379 & 293 \\
Adjusted $\mathbf{R}^{2}$ & .13 & .23 \\
$\mathbf{F}$ & $3.77^{* * *}$ & $5.31^{* *}$ \\
\hline
\end{tabular}

\section{Coefficients}

Coefficients

Adolescent's education

(omitted=did not complete primary)

Completed primary

Completed preparatory

Above preparatory

Mother's education (omitted=no schooling)

Did not complete primary

Completed primary/any preparatory

Vocational, above intermediate

Secondary and above

$-.44$

Missing

Father's education (omitted=no schooling)

Did not complete primary

Completed primary/any preparatory

Vocational, above intermediate

Secondary and above

Missing

\section{Residence (omitted=Upper Egypt, rural)}

Upper Egypt, urban

Lower Egypt, rural

Lower Egypt, urban

Urban governorates

\section{Socioeconomic status (omitted=low)}

Medium

High

Missing

Constant

Note: Differences between boys and girls significant at ${ }^{*} \mathrm{p}<.05 ; * * \mathrm{p}<.01 ; * * * \mathrm{p}<.001$. 
residence in urban areas appears to affect adoption of a more equitable conception of gender roles.

\section{SUMMARY AND CONCLUSIONS}

This paper has explored a number of facets of gender role socialization among Egyptian adolescents. We first examined education as the pivotal life experience that separates this generation from that of their parents, when a much smaller percentage benefited from schooling. Among today's adolescents, education is not yet equally available to boys and girls, although the disparity in school access continues to become smaller. Once in school, however, girls and boys have the same chance of continuing to higher levels, an important and relatively new achievement.

We subsequently analyzed time use, finding substantial differences in the ways in which adolescent boys and girls occupy themselves. Boys tend to spend time outside their homes, engaged in activities with friends or visiting relatives or friends in their homes. They are also considerably more likely to participate in paid work, while girls participate in domestic work within the household. Girls' participation in domestic work is high, varies little by age, and is consistently higher than boys' participation even when accounting for school enrollment. The fact that younger boys report fairly high participation in domestic tasks at rates that decline in later adolescence is consistent with the notion that older boys are consolidating their adult male positions by distancing themselves from the tasks of children and women. Moreover, Egyptian boys have significantly more contact with peers than girls do, and gain more freedom with age.

Boys are more likely to favor traditional marriage arrangements, while girls are somewhat more egalitarian. Boys favor earlier marriage ages for both sexes-but particularly for men-than do girls. The wide differences in what boys and girls say they are seeking in an ideal spouse would serve well in highly role-segregated marriages, but not in those in which both spouses work and earn. In addition, boys at all educational levels are significantly more likely than girls to think that a husband should have more education than a wife. One expects that some of these gender preferences may be challenged by the economic and social realities this generation will face as they enter adulthood.

The one inconsistent finding with regard to gender differences in attitudes is that girls, particularly those who are better educated, are more likely than boys to favor a 
large age difference between spouses. The demographic literature on women's status and fertility argues that age difference, rather than age at marriage, is a significant predictor of gender inequality and women's status in society (Cain 1984; Amin and Cain 1997), although this view has been recently challenged (Balk 1997). While a preference for a large age difference could represent a traditional attitude, another, perhaps more plausible explanation is that, in Egypt, girls believe a large gap is necessary because it takes men longer to become economically ready for marriage.

In general, both girls and boys support a traditional division of roles between men and women, although girls are somewhat less conservative than boys. While the vast majority of adolescent girls and boys believe that a wife "needs her husband's permission for everything," girls are significantly less likely than boys to say that a wife must accept her husband's opinion or defer to him on household discretionary spending or decisions about childbearing. Moreover, girls are significantly more likely than boys to prefer sharing of household decisionmaking with their future spouses.

Table 14 summarizes the gender differences that have been explored in this paper: for every aspect of adolescent socialization we investigated, there is a "gender gap" between the attitudes of boys and girls. The question is whether the gender gap observed here will have an effect on women's autonomy in adulthood. Will the somewhat more egalitarian attitudes of adolescent girls begin to undermine traditional gender roles later in marriage? And, if so, will increases in the empowerment of married women promote demographic change as the Programme of Action at the International Conference on Population and Development proclaimed (United Nations 1995)? Alternatively, will the emerging differences in gender role preference continue to widen, creating tension and conflict as new generations of married couples negotiate their domestic lives?

In addition to investigating the gender gap in adolescent socialization, we examined factors that might account for differences in gender role attitudes. Our bivariate and multivariate models were not entirely successful in explaining differences in gender role socialization (see Table 15). We predicted that education would be a key explanatory factor with regard to the attitudes explored in this paper. It is for some dimensions but not for others, a finding consistent with research on the determinants of gender role behavior among married women in developing countries (Kishor 1999; Balk 1997). Indeed in a DHS sample of married women in Egypt, education was not consistently 
Table 14 Summary of gender differences in adolescent socialization

\begin{tabular}{ll}
\hline & Nature of difference \\
\hline Time use & Girls have heavier domestic burden, less mobility. \\
$\begin{array}{l}\text { Attitudes toward marriage } \\
\text { Suitable age at marriage for women }\end{array}$ & Girls favor older age. \\
$\begin{array}{l}\text { Suitable age at marriage for men } \\
\text { Characteristics of spouse }\end{array}$ & Girls favor older age. \\
& $\begin{array}{l}\text { Girls prefer a husband who has strong character, good nature, } \\
\text { treats her well, has wealth, and a good job. }\end{array}$ \\
& Boys prefer a wife who is virtuous, religious, polite, and \\
from good family. \\
Age difference between spouses & Girls less likely to think husband should be better educated. \\
Attitudes toward gender roles & Girls favor larger age difference. \\
Wife not deferential to husband & Girls more likely to think wife should not be deferential. \\
Spouses share decisionmaking & Girls more likely to support shared decisionmaking. \\
Spouses share tasks & Girls more likely to support sharing of household tasks. \\
\hline
\end{tabular}

related to two empowerment indexes measuring decisionmaking and freedom of movement (Kishor 1999). While our multivariate models reveal that better-educated adolescent girls and boys are significantly more likely to approve a later age at marriage for women, in terms of attitudes toward men's age at marriage, education is significantly and positively associated with boys favoring a later age, but not girls. Moreover, education is not, for either sex, significantly related to time use, attitudes toward spouse characteristics, attitudes concerning whether the husband should be better educated than the wife, or to attitudes about task sharing. While education is significantly related to sharing of decisionmaking in bivariate models for both boys and girls, this effect disappears in a multivariate model.

While education appears to be central to creating opportunities for young people in Egypt, clearly it does not always challenge the expression of traditional attitudes for either sex or necessarily encourage wider horizons for girls. Given that the school curriculum has supported traditional gender roles in Egypt, modifying the content of education for children and adolescents is likely to be critical in effecting attitude change. A revised school curriculum or auxiliary materials that focus on gender roles might help to 
Table 15 Summary of effects of adolescent education on gender role socialization

\begin{tabular}{lcc}
\hline & Girls & Boys \\
\hline Time use & N.S. & N.S. \\
Attitudes toward marriage & & \\
Suitable age at marriage for women & Positive & Positive \\
Suitable age at marriage for men & N.S. & Positive \\
Characteristics of spouse & N.S. & N.S. \\
Husband better educated than wife & N.S. & N.S. \\
Age difference between spouses & Negative & Negative \\
Attitudes toward gender roles & & \\
Wife not deferential to husband & Positive & Positive \\
Spouses share decisionmaking & Positive & Positive \\
Spouses share tasks & N.S. & N.S. \\
\hline
\end{tabular}

Note: N.S.=not significant.

${ }^{a}$ Not significant in multivariate models; only bivariate association significant.

bring perceptions more in line with local realities in the home and workplace. The example of individual adult role models who challenge stereotypes could be used more effectively by both educators and the media. Given the very high level of young people's exposure to mass media, television serials and dramas could be effectively employed to address salient issues, such as early age at marriage and negotiating gender roles within marriage.

In light of some of the contradictions inherent in adolescents' stated gender views, more in-depth research is needed to explore the relationship between their verbal expressions and other manifestations of gender beliefs. An earlier study of employed women in Egypt found, for example, that by adopting nontraditional work roles, these women felt obligated to assert more conservative viewpoints regarding their acquiescence to husbands' authority at home (Ibrahim 1980).

The greater physical mobility of boys suggests that communication of gender role messages through neighborhood centers, sports facilities, work sites, and other gathering places could be effectively mobilized. On the other hand, girls' relative isolation in the home, especially for nonstudents, will require creative programs to carve out 
"safe spaces" where they can gather and learn. Girls' restricted access to sports and other physical activities is a concern from both a health and a developmental perspective. Experiments are needed that show how community and family support could be generated for appropriate physical activity for adolescent girls. Finally, since the preference of adolescents, particularly boys, for segregated roles may come into conflict with changing economic and social realities for families, discussion of gender roles would be an important topic for debate in youth clubs and NGO programs that are preparing young people for adult responsibilities.

\section{Notes}

The authors gratefully acknowledge the four institutions responsible for the Adolescence and Social Change in Egypt survey: the Social Research Center, American University in Cairo; the High Institute of Public Health, Alexandria University; the Department of Public Health and Community Medicine, Assiut University; and the Population Council, Cairo, Egypt. The survey was conducted under the auspices of the Egyptian Ministry of Health and Population, whose support is gratefully acknowledged. We would also like to thank Sahar El-Tawila and Wesley Clark, who provided technical assistance for parts of the analyses. The authors gratefully acknowledge the helpful comments of Harriet Presser on an early version of the paper focused only on boys and Cynthia Lloyd and Sajeda Amin for helpful comments on the current version. Financial support for this research was provided by the Rockefeller Foundation, the Canadian International Development Agency (CIDA), the Government of the Netherlands, UNFPA, and UNICEF.

1 Earlier analysis of socialization in this sample was included by the authors in a Population Council report (El-Tawila et al. 1999).

2 A small literature from the Middle East focuses on masculinity and sexuality (see Ali 1996; Boudhiba 1985), although adolescents are not explicitly examined. There is one other ethnographic study on adolescents from the region, in addition to the Morocco study discussed above. Joseph (1994) explores how siblings prac- 
tice their gender roles on each other and describes how brothers, perhaps even more than fathers, enforce patriarchal norms by ensuring that their sisters conform to expected behavior.

3 The ASCE survey is a nationally representative, multi-stage probability sample of adolescents aged 10-19. In the first stage, 101 primary sampling units (PSUs) were selected, proportional to population size, using the updated census frame of PSUs compiled by CAPMAS (Egypt's census bureau). The primary sampling units were stratified by 21 governorates and by urban/rural residence within each governorate. In the second stage, two segments were randomly selected from each of the 101 primary sampling units. All households within the selected segments were screened for age-sex composition of usual household. A total of 13,271 households were screened. Eligible households were then defined as those with at least one member between ages 10 and 19 years. Using the Kish grid, one adolescent of each sex in the 10-19 age range was randomly selected from each of the 7,256 eligible households. A total of 9,128 adolescents were interviewed (4,354 boys and 4,774 girls). Boys serving in the military were likely to be living outside the household and are probably underrepresented. An interview was also administered to a responsible adult in each household in which at least one adolescent was interviewed. One parent was randomly selected in two-parent households, while in single-parent basic family units, the parent who is a member of the sampled household was interviewed. This strategy ensured a fair representation of mothers/female caretakers and fathers/male caretakers. A total of 6,213 adults were interviewed (3,274 men and 2,939 women).

4 Where comparisons by age can be made, e.g., the time-use analysis, adolescents between the ages of 10 and 15 are included.

5 The household consumption index includes: 1) conditions of the housing unit, 2) ownership of durable goods, 3) ownership of assets and vehicles, 4) mean monthly expenditure per household member, and 5) mean monthly expenditure on the education of each adolescent. Each of the first three components is weighted on the basis of relative frequencies in each household; the latter two are standard- 
ized among all households. The final index sums the five standardized subcomponents and then divides it into three equal categories.

6 Of course, since a smaller proportion of girls enter school to begin with, those who do attend are likely to be a selective sample by comparison to boys and therefore should be expected to perform as well as or better than boys. Our data also suggest that gender differences may exist in the reasons for dropping out, with older boys more likely to drop out because of competing work opportunities.

$7 \quad$ For 8 percent of adults the length of time they thought boys and girls should stay in school could not be determined because they did not give numerical responses.

8 A question about the benefits of education was also asked of adolescents, but because it was limited to those currently in primary, preparatory, and secondary school, excluding those not in school and those attending university or a vocational institute, analysis of it is not included here.

9 Because the interviews were conducted seven days per week during part of the academic year and school holiday, in order to capture variations in activity throughout the week and throughout the year, the findings average the experience of adolescents. The questions were not sufficiently detailed to permit computation of time spent in a specified activity.

10 Since more boys than girls combine school and wage work in Egypt, it would be useful to understand whether boys' additional responsibilities outside the home are replacing work within the home. Small sample sizes do not permit us to investigate this.

11 Every pair-wise comparison between the sexes for the question concerning men's marriage age indicates an older age desired by girls than by boys. For the question concerning women's marriage age, this pattern holds in six of nine categories; the exceptions are those who have completed primary school and those who live in urban lower Egypt and urban upper Egypt.

12 Further support for these hypotheses regarding the appropriate age at marriage is provided by the reasons given. When asked why the particular ages for boys and 
girls are considered suitable, responses are not consistent according to the age given, except when the responses relate to finding a job for men and education for women. Responses about understanding life, health, and finishing the military for men are given by those who advocate early as well as late marriage, as are responses citing ideal age to raise children, tradition, dealing with people, obeying husband, ability to manage household, and securing employment for women. On the other hand, boys who cite having a job for men and both boys and girls who cite finishing education for women are much more likely to give older ages. For example, 69 percent of boys who say that 30 or older is a suitable age for men to marry cite the need to have a job, compared to 35 percent who say that ages 21-24 are suitable. Over 40 percent of girls and boys who give an age of 22 or higher for female marriage cite finishing education, compared to 4 percent of those who give an age below 18 .

13 The one clear exception is the desire for an educated spouse. While there is no systematic association between wanting an educated spouse and level of respondent's education, those adolescents who have gone beyond preparatory school (grades 6-8) are much more likely to mention wanting an educated spouse than are those who have received less schooling. Whereas approximately 30 percent of boys who completed primary or preparatory school and 46 percent of boys who have gone beyond preparatory school mentioned education as a desirable quality in a spouse, not one boy with lower levels of education mentioned female education as a desirable attribute.

14 For example, 8 percent of girls who completed primary school believe that a husband should be more educated than his wife, compared to 30 percent of girls who did not complete primary school, 29 percent of those who completed preparatory school, and 30 percent of those who have gone beyond preparatory school. The comparable percentages for boys are 59 percent (did not complete primary), 47 percent (completed primary), 42 percent (completed preparatory school), and 43 percent (beyond preparatory school).

15 In the multivariate model, the coefficient for the highest educational category is also significant for boys, although it is smaller in magnitude than for girls. 
16 Because the range in the attitude score for the dependent variable "wife not deferential to husband" is $0-4$, OLS may be inappropriate. Thus we also ran an ordered logit model as well as a standard logit model after collapsing the dependent variable into two categories, where $0=$ yes to all four components signifying complete support of the notion that a wife should be deferential to her husband (36 percent of boys and 29 percent of girls) and 1= otherwise (64 percent of boys and 71 percent of girls). (See Table 8 for the four components). The results for the ordered logit are virtually the same in terms of signs of coefficients and significance; only one variable in one model, "upper Egypt, urban" for boys, is significant in the logit and not in the OLS. The signs of the coefficients are by and large the same for the standard logit; however, three variables- "father's secondary education and above" for boys and the two residence variables for girls - are not significant in the logit and are in the OLS. In all three models for both sexes, the signs and significance levels are the same for the adolescent education variable.

\section{References}

Alan Guttmacher Institute. 1998. Into a New World: Young Women's Sexual and Reproductive Lives. New York.

Ali, K. 1996. "Notes on rethinking masculinities: An Egyptian case, " in S. Zeidenstein and K. Moore (eds.), Learning About Sexuality: A Practical Beginning. New York: Population Council, pp. 98-109.

Amin, S. and M. Cain. 1997. "The rise of dowry in Bangladesh," in G.W. Jones et al. (eds.), The Continuing Demographic Transition. Oxford: Clarendon Press: 290306.

Balk, D. 1997. "Defying gender norms in rural Bangladesh: A social demographic analysis,” Population Studies 51 (2):153-172.

Bouhdiba, A. 1985. Sexuality in Islam. London: Routledge.

Cain, M. 1984. "Women's status and fertility in developing countries: Son preference and economic security," World Bank Staff Working Paper no. 682. Washington, DC. 
Davis, S.S. and D.A. Davis. 1989. Adolescence in a Moroccan Town: Making Social Sense. New Brunswick, NJ: Rutgers University Press.

Durrant, V. and Z. Sathar. 2000. "Greater investments in children through women's empowerment: A key to demographic change in Pakistan?" Paper presented at the Population Association of America Annual Meeting, Los Angeles, March. Also published as Policy Research Division Working Paper no. 137.

Dyson, T. and M. Moore. 1983. "On kinship structure, female autonomy, and demographic behavior in India," Population and Development Review 9 (1): 35-60.

El-Kholy, H. 1997. "Gender politics in low-income Cairo.” Occasional Papers. Cairo: Population Council, Regional Office for West Asia and North Africa.

El-Tawila, S. et al. 1999. Transitions to Adulthood: A National Survey of Egyptian Adolescents. Cairo: Population Council.

El-Zanaty, F.H. et al. 1996. Egypt Demographic and Health Survey 1995. Cairo and Calverton, MD: National Population Council (Arab Republic of Egypt) and Macro International, Inc.

Federici, N., K.O. Mason, and S. Sogner (eds.). 1993. "Introduction" to Women's Position and Demographic Change. Oxford: Clarendon Press, pp. 1-15.

Furnham, A. and B. Stacey. 1991. Young People's Understanding of Society. London: Routledge.

Hoodfar, H. 1997. Between Marriage and the Market: Intimate Politics and Survival in Cairo. Berkeley: University of California Press.

Hossain, M., J. Phillips, B. Pence, and I. Diamond. 2000. "The effects of constrained women's status on infant and child mortality in four rural areas of Bangladesh," paper presented at the Annual Meeting of the Population Association of America, Los Angeles, CA, March.

Ibrahim, B. 1980. "Social change and the industrial experience: Women as production workers in urban Egypt," Ph.D. diss., Indiana University.

Ibrahim, B. and H. Wassef. 2000. "Caught between two worlds: Youth in the Egyptian hinterland," in R Meijer (ed.), Youth and Culture in the Arab World. London: Curzon Press. 
Jeffery R. and A.M. Basu. 1996. "Schooling as contraception?" in R. Jeffery and A.M. Basu (eds.), Girls' Schooling, Women's Autonomy and Fertility Change in South Asia. New Delhi: Sage Publications, pp. 15-47.

Jejeebhoy, S.J. 1995. Women's Education, Autonomy, and Reproductive Behaviour: Experience from Developing Countries. Oxford: Clarendon Press.

Joseph, S. 1993. "Connectivity and patriarchy among urban working-class Arab families in Lebanon," Ethos 21(4):452-484.

_ 1994. "Brother/sister relationships: Connectivity, love and power in the reproduction of Arab patriarchy," American Ethnologist 21(1):51-73.

Kandiyoti, D. 1994. "The paradoxes of masculinity: Some thoughts on segregated societies," in A. Cornwall and N. Lindisfarne (eds.), Dislocating Masculinity: Comparative Ethnographies. London: Routledge, pp. 197-213.

Kishor, S. 1995. Autonomy and Egyptian Women: Findings from the 1988 Egypt Demographic and Health Survey. Calverton, MD: Macro International, Inc.

_ 1999. "Women's empowerment and contraceptive use in Egypt," paper presented at the Annual Meeting of the Population Association of America, March, New York.

__ 2000. "Women's contraceptive use in Egypt: What do correct measures of empowerment tell us?" paper presented at the annual meeting of the Population Association of America, Los Angeles, CA, March.

Lloyd, C.B. and B.S. Mensch. 1999. "Implications of formal schooling for girls' transitions to adulthood in developing countries," in C.H. Bledsoe, J.B. Casterline, J.A. Johnson-Kuhn, and J.G. Haaga (eds.), Critical Perspectives on Schooling and Fertility in the Developing World. Washington, DC: National Academy Press, pp. 80-104.

Mason, K.O. 1987. "The impact of women's social position on fertility in developing countries," Sociological Forum 2(4): 718-745.

__ 1993. "The impact of women's position on demographic change during the course of development," in N. Federici, K.O. Mason, and S. Sogner (eds.), Women's Position and Demographic Change. Oxford: Clarendon Press. pp. 19-42. 
McCauley, A.P. and C. Salter. 1995. "Meeting the needs of young adults," Population Reports, Series J, October (41): 1-43.

Mensch, B.S., J. Bruce, and M.E. Greene. 1998. The Uncharted Passage: Girls'Adolescence in the Developing World. New York: The Population Council.

Morris, L. 1994. "Sexual behavior of young adults in Latin America," Advances in Population 2:231-252.

Naguib, N.G. and C.B. Lloyd. 1994. Gender Inequalities and Demographic Behavior: Egypt. New York: Population Council.

Nawar, L., C.B. Lloyd, and B. Ibrahim. 1995. "Women's autonomy and gender roles in Egyptian families," in C.M. Obermeyer (ed.), Family, Gender, and Population in the Middle East: Policies in Context. Cairo: American University in Cairo Press, pp. 147-178.

Raymundo, C.M., P. Xenos, and L.J. Domingo. 1999. Adolescent Sexuality in the Philippines. Quezon City: University of the Philippines, Population Institute.

Rugh, A. 1999. Within the Circle: Parents and Children in an Arab Village. New York: Columbia University Press.

Said, E. 1978. Orientalism. London: Routledge and Kegan Paul.

Sayed, H. and F. El-Zanaty. 1993. "Male role in decision making in Egypt," presented at the International Population Conference, 24 August-1 September, Montreal.

Sayed, H., F. El-Zanaty, and A. Cross. 1992. Egypt Male Survey, 1991. Cairo and Columbia, MD: Cairo Demographic Center and Macro International, Inc.

Schlegel, A. (ed.). 1995a. “Introduction,” Special Issue on Adolescence, Ethos 23(1):314.

__ (ed.). 1995b. "A cross-cultural approach to adolescence," Special Issue on Adolescence, Ethos 23(1):15-32.

Schlegel, A. and H. Barry, III. 1991. Adolescence: An Anthropological Inquiry. New York: Free Press.

Singh, S. and R. Samara. 1996. "Early marriage among women in developing countries," International Family Planning Perspectives 22 (4): 148-157, 175. 
Singh, S., D. Wulf, R. Samara, and Y.P. Cuca. 2000. "Gender differences in the timing of first intercourse: Data from 14 countries," International Family Planning Perspectives 26 (1):21-28, 43.

Tessler, A., M. Palmer, T. Farah, and B. Ibrahim. 1987. The Evaluation and Application of Survey Research in the Arab World. Boulder, CO: Westview Press.

Uchudi, J. 2000. Gender Context and Fertility Differences in Sub-Saharan Africa. Center on Population, Gender, and Social Inequality, University of Maryland.

United Nations. 1995. World Urbanization Prospects: The 1994 Revision. New York: United Nations.

Wassef, H. 1996. "Constructions of gender in middle and secondary school curriculum in Egypt," in Proceedings of the Arab Regional Population Conference, International Union for the Scientific Study of Population, Cairo, Egypt, pp. 324-351.

Youniss, J. 1989. "Parent-adolescent relationships," in W. Damon (ed.), Development Psychology Today and Tomorrow. San Francisco: Jossey-Bass, pp. 379-392. 


\section{POLICY RESEARCH DIVISION WORKING PAPERS}

Recent Back Issues

1998

*106 Sajeda Amin and Gilda Sedgh, "Incentive schemes for school attendance in rural Bangladesh."

107 Martin Brockerhoff and Paul Hewett, "Ethnicity and child mortality in sub-Saharan Africa."

108 Ann E. Biddlecom and Bolaji M. Fapohunda, "Covert contraceptive use: Prevalence, motivations, and consequences."

109 John Bongaarts and Griffith Feeney, "On the quantum and tempo of fertility."

110 Barbara S. Mensch, Daniel Bagah, Wesley H. Clark, and Fred Binka, "The changing social environment for adolescents in the Kassena-Nankana District of northern Ghana: Implications for reproductive behavior."

111 Martin Brockerhoff and Ann Biddlecom, "Migration, sexual behavior, and HIV diffusion in Kenya."

112 Zeba A. Sathar and John B. Casterline, "The onset of fertility transition in Pakistan."

113 Geoffrey McNicoll, "Government and fertility in transitional and posttransitional societies."
*114 John Bongaarts, "Fertility and reproductive preferences in post-transitional societies."

115 Fiona Steele, Sajeda Amin, and Ruchira T. Naved, "The impact of an integrated micro-credit program on women's empowerment and fertility behavior in rural Bangladesh."

*116 Cynthia B. Lloyd, Barbara S. Mensch, and Wesley H. Clark, "The effects of primary-school quality on the educational participation and attainment of Kenyan girls and boys."

*117 Sajeda Amin and Cynthia B. Lloyd, "Women's lives and rapid fertility decline: Some lessons from Bangladesh and Egypt."

118 James F. Phillips and Mian Bazle Hossain, "The impact of family planning household service delivery on women's status in Bangladesh."

*119 Mark R. Montgomery and John B. Casterline, "Social networks and the diffusion of fertility control."

* No longer available 
*120 John Bongaarts, "The fertility impact of changes in the timing of childbearing in the developing world."

*121 James F. Phillips, Wendy L. Greene, and Elizabeth F. Jackson, "Lessons from community-based distribution of family planning in Africa."

122 Mark R. Montgomery, "Mortality decline and the demographic response: Toward a new agenda."

*123 Mark R. Montgomery, Mary ArendsKuenning, and Cem Mete, "The quantity-quality transition in Asia."

124 Barbara S. Mensch, Wesley H. Clark, Cynthia B. Lloyd, and Annabel S. Erulkar, "Premarital sex and school dropout in Kenya: Can schools make a difference?"

125 John Bongaarts and Rodolfo A. Bulatao, "Completing the demographic transition."

126 Geoffrey McNicoll, "Population weights in the international order."
127 Cynthia B. Lloyd, Carol E. Kaufman, and Paul Hewett, "The spread of primary schooling in sub-Saharan Africa: Implications for fertility change."

128 John B. Casterline, "The onset and pace of fertility transition: National patterns in the second half of the twentieth century."

129 Mark R. Montgomery, Michele Gragnolati, Kathleen Burke, and Edmundo Paredes, "Measuring living standards with proxy variables."

130 Bamikale Feyisetan and John B. Casterline, "Fertility preferences and contraceptive change in developing countries."

131 Martin Brockerhoff, "Urban growth in developing countries: A review of projections and predictions."

132 Omaima El-Gibaly, Barbara Ibrahim, Barbara S. Mensch, and Wesley H. Clark, "The decline of female circumcision in Egypt: Evidence and interpretation."

* No longer available 
133 Mary Arends-Kuenning and Sajeda Amin, "The effects of schooling incentive programs on household resource allocation in Bangladesh."

134 John Bongaarts and Charles F. Westoff, "The potential role of contraception in reducing abortion."

135 John B. Casterline and Steven W. Sinding, "Unmet need for family planning in developing countries and implications for population policy."

136 Carol E. Kaufman, Thea de Wet, and Jonathan Stadler, "Adolescent pregnancy and parenthood in South Africa."

137 Valerie L. Durrant and Zeba A. Sathar, "Greater investments in chil- dren through women's empowerment: A key to demographic change in Pakistan?"

138 Sajeda Amin, Alaka Malwade Basu, and Rob Stephenson, "Spatial variation in contraceptive use in Bangladesh: Looking beyond the borders."

139 Geoffrey McNicoll, "Managing population-environment systems: Problems of institutional design."

140 Barbara S. Mensch, Barbara L. Ibrahim, Susan M. Lee, and Omaima ElGibaly, "Socialization to gender roles and marriage among Egyptian adolescents." 